\title{
The use of NPWT in combination with silver dressing in diabetic foot syndrome - case report
}

\author{
Dominik A. Walczak, $M D^{*}$, Rajmund Jaguścik, $M D$, Karolina Ptasińska, $M D$, Leokadia Kozaczek, Piotr W. \\ Trzeciak, $M D$
}

\begin{abstract}
Patients with diabetes mellitus are at increased risk of angiopathy, neuropathy and infection compared with healthy individuals and this may lead to foot disorders. Treatment is difficult challenging and if it is not successful it often leads to lower limbs amputations.

We present a case report of 63 years old man after amputation of big toe and part of metatarsus due to diabetic foot syndrome, successfully treated with negative pressure wound therapy in combination with silver dressing. The literature regarding this issue was also reviewed.
\end{abstract}

Keywords-diabetic foot syndrome, negative pressure wound therapy, skin graft, silver dressing

\section{INTRODUCTION}

$\mathbf{P}$ ATIENTS with diabetes mellitus (DM) are at increased risk of angiopathy and neuropathy compared with healthy individuals and that may lead to diabetic foot syndrome (DFS) development. Foot ulceration, infection and gangrene in course of DFS are significant complications of the disease and main cause of hospitalization. 1 Moreover foot disorders are the leading cause of nontraumatic amputation and can be 15 to 40 times among the diabetic versus nondiabetic population. Tragically, the 5-year survival rate after a diabetes-related lower limb amputation has been reported as approximately $30 \%{ }^{2}$ and is lower in comparison to some neoplastic diseases! 3 .

Recently the negative pressure wound therapy (NPWT) received recognition in treatment of acute and chronic wounds. NPWT can be used to cure various types of wounds associated with diabetic lower extremity disease. It can be applied to a chronic diabetic foot ulcers (DFU) non-respondent to alternative therapies and also wounds in the diabetic limbs following surgical debridement or partial amputation 5 . 6

The use of negative pressure in conjunction with silver provides an important evolution in NPWT concept with the potential added profit of supplying an antimicrobial agent to the infected wound bed. ${ }^{7}$ This article describes our idea of treatment the patient with diabetic foot syndrome, using NPWT in combination with silver dressing.

Manuscript received 9.2014; revised 10.2014

Author affiliation: Department of General Surgery, John Paul II Memorial Hospital in Bełchatów, Poland, Address: Szpital Wojewódzki im Jana Pawła II w Bełchatowie, Oddział Chirurgiczny Ogólny, ul. Czapliniecka 123, 97-400 Bełchatów, (WDA, JR, PK, KL, TPW)

*Correspondence to: Dominik Walczak (e-mail:

\section{CASE REPORT}

A 63 years old man was admitted to our ward due to necrosis of the left big toe and foot phlegmon in course of DFS. Aside from diabetes mellitus patient suffered also from the end stage renal disease and required hemodialysis. In his past medical history he underwent the amputation of his right leg below knee level in 1998 however prosthetic leg allowed him to walk. In 1999 he received the kidney transplant but the donated organ was rejected 13 years later.

At the moment of admittion the patient was in fair general condition, with fever of $38.5^{\circ} \mathrm{C}$. The physical examination reveled necrosis of the left big toe and massive inflammation of the medial site of the metatarsus with fluctuance (University of Texas Classification System - III D).

Laboratory studies showed features of inflammatory response: leukocytosis with left shift and elevated $\mathrm{C}$ reactive protein. The ankle-brachial index was 0.8 . The radiogram revealed decreased density of foot bones and small lytic lesions of big toe phalanges.

Intravenous cefuroxime was started empirically. Antibiotic regimens were changed considering the culture results. ciprofloxacin was administered for Citrobacter freundii in appropriate doses upon the results of antibiogram test.

On the day of admission the amputation of big toe, debridement, and drainage were performed. Operating surgeon had to remove necrotic tissues of the medial plantar space with significant part of the first metatarsal bone. On the fourth day of hospitalization patient was re-operated on to remove persistent necrotic tissues (Fig. 1 1 and b). From the fifth day we started the negative pressure wound therapy.

The wound was lined with a layer of silver containing dressing (Atrauman Ag - non-adherent, polyester tulle, impregnated with neutral triglycerides and silver ions, PAUL HARTMANN AG, Germany) and then the NPWT polyurethane foam (VivanoMed Foam, PAUL HARTMANN AG, Germany) was applied on it (Fig. 11-e). The pump was set to a continuous negative pressure of $120 \mathrm{mmHg}$. Dressings were changed every second day. After 48 hours, the pressure mode was switched to intermittent negative pressure at $-120 \mathrm{mmHg} /-20 \mathrm{mmHg}$. (Fig. 1f, g)

After 18 days of NPWT therapy ( 9 dressing changes) the wound was determined to be clean by clinical assessment and adequate granulation tissue formation was achieved (Fig. 1 h), the meshed split-thickness skin grafts were applied (Fig. dr.dominikwalczak@gmail.com). 


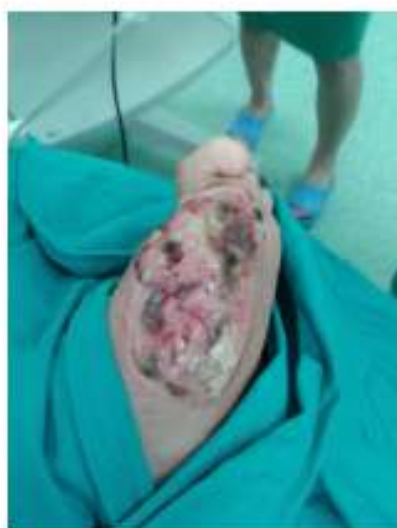

Fig. 1a

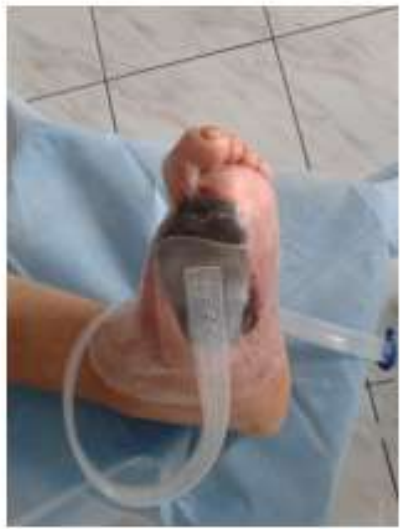

Fig. 1e

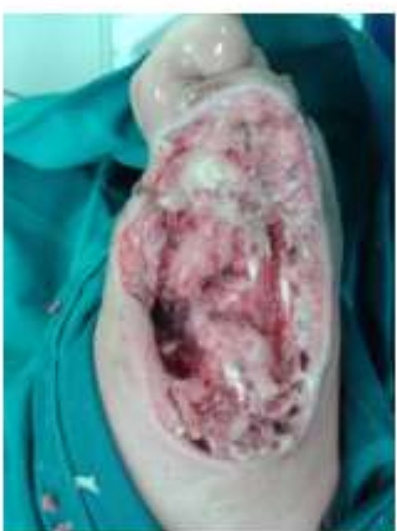

Fig. 1b

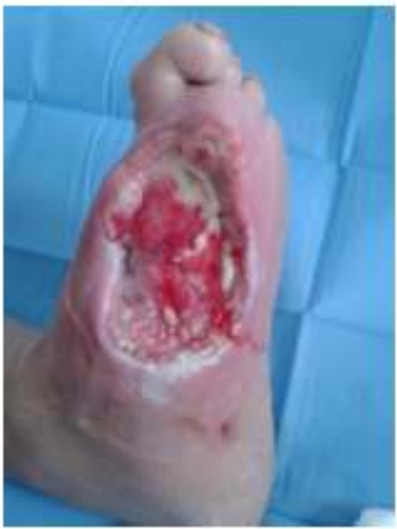

Fig. 1f

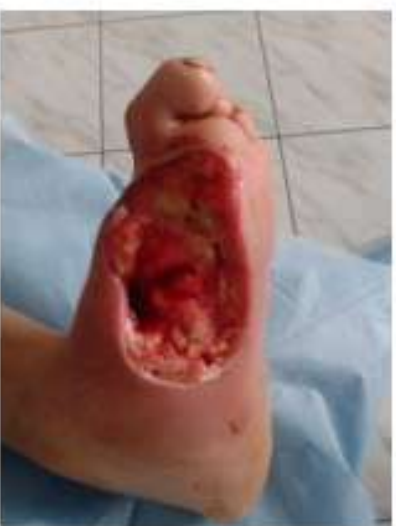

Fig. 1c

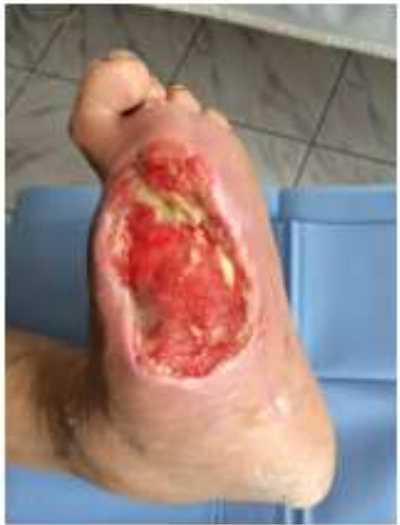

Fig. $1 \mathrm{~g}$

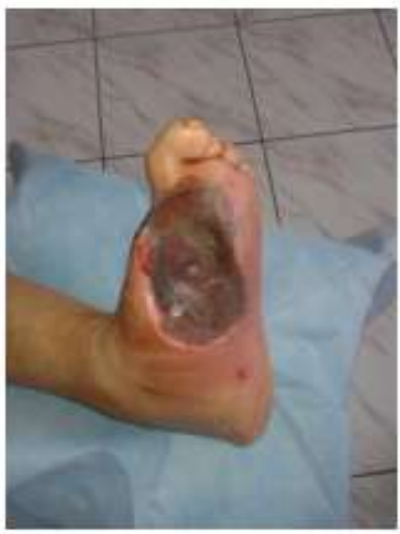

Fig. 1d

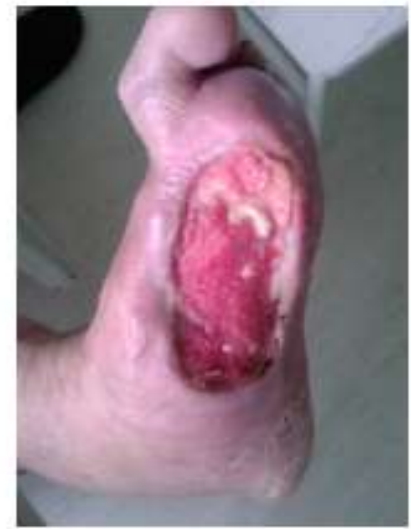

Fig. 1h

Figure 1. a) the wound after amputation of big toe and removal of necrotic tissues of the medial planar space, before second debridement; b) the wound after debridement; c) wound before application of NPWT; d, e) the wound lined with a layer of silver containing dressing and then polyurethane foam; f) the wound after 8 days negative pressure therapy; g) after 12 days; h) the wound's bed filled with granulation tissue after 18 days of NPWT.

2a). The Atrauman $\mathrm{Ag}$ was used as a primary dressing for skin grafts and covered with NPWT dressing kit with continuous negative pressure of $85 \mathrm{mmHg}$ (Fig. 2p, c). The NPWT dressings were changed on the third day after grafts application. We removed only the polyurethane foam however the primary dressing (Atrauman Ag) remained untouched (Fig. $2 \mathrm{~d}$ ). The whole dressing (NPWT and polyester tulle with silver ions) was changed on the 5th day after grafts application (Fig. 22). Approximately $95 \%$ of grafts surface was vital. Negative pressure wound therapy was continued until it was considered that the graft's uptake was completed (3 NPWT dressing changes after grafts application were administered in total). The patient was released from the hospital on 32 day of treatment (Fig. 25). The patient was examined on weekly follow-up visits after discharge (Fig. $2 \mathrm{~g}$ ).

\section{DISCUSSION}

The negative pressure wound therapy (NPWT) sometimes referred to as vacuum-assisted closure (VAC), subatmospheric pressure dressing (SPD) or topical negative pressure (TNP) has revolutionized wound care over the last years. 8
The accurate mechanism of NPWT action is not clear, however it gives the number of beneficial clinical effects. $\frac{9}{}$ It creates a moist environment, improves fluid removal, reduces tissue oedema, contracts the wound, mechanically stimulates the wound bed, induces cell proliferation, alters blood flow in the wound edges, stimulates neoangiogenesis and the formation of granulation tissue? 13

The effect of NPWT on bacterial colonization of wounds is controversial. On one hand sealed environment created by airtight film goes against traditional wisdom with regard to the management of infected wound with free drainage. ${ }^{14}$ On the other, suction device may improve bacterial clearance 15 Studies have shown that removing bacteria from the wound is important because bacterial colonization delays or prevents wound healing!

In 1997 Morykwas and Argenta demonstrated that application of negative pressure to infected experimental porcine wounds reduced bacterial numbers significantly compared to traditional dressing. This evidence has become the basis for the widespread belief that VAC contributes towards bacterial 


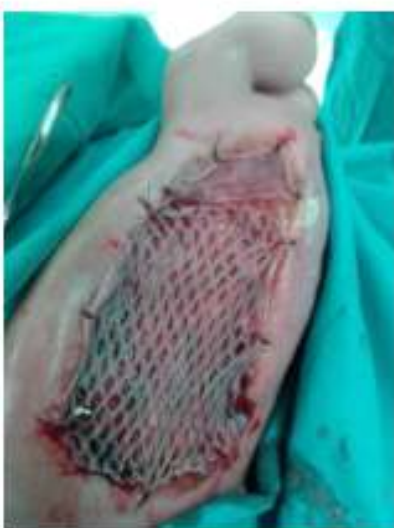

Fig. 2a

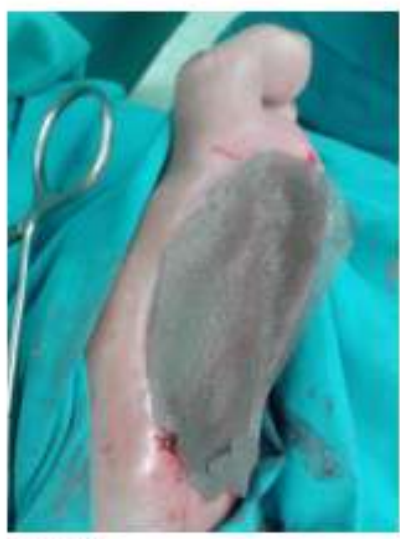

Fig. $2 \mathrm{~b}$

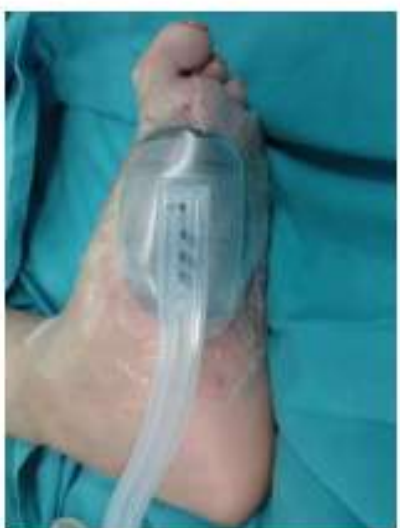

Fig. $2 c$

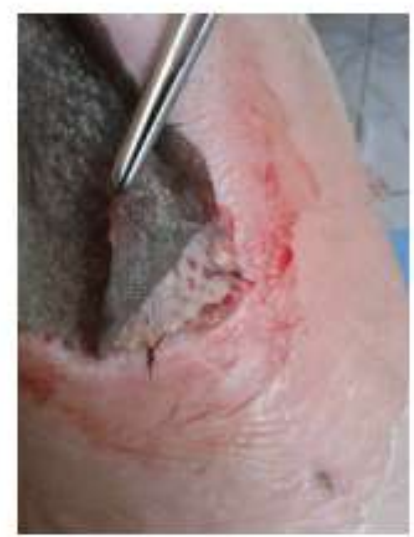

Fig. 2d

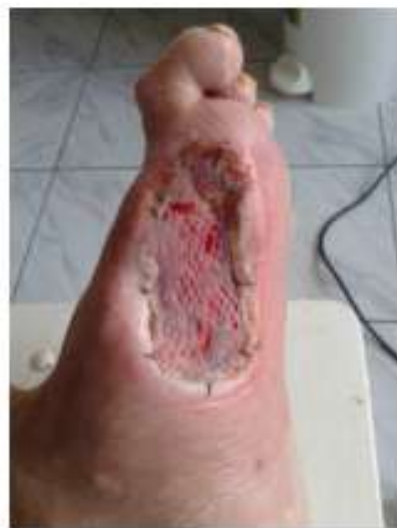

Fig. $2 \mathrm{e}$

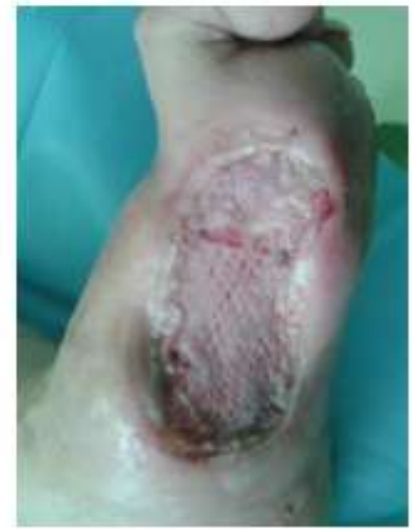

Fig. $2 \mathrm{f}$

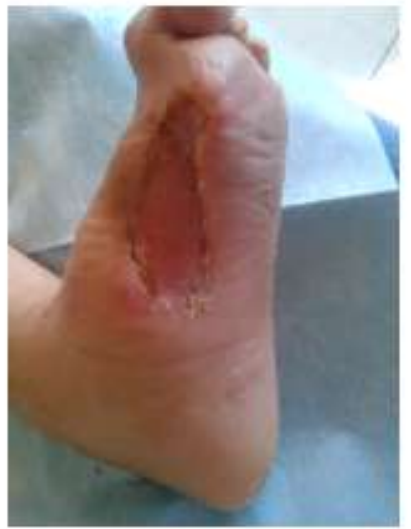

Fig. $2 \mathrm{~g}$

Figure 2. a), b), c) application of meshed split-thickness skin grafts covered with silver impregnated dressing and NPWT; d) first dressing change after grafts' application, polyurethane foam was removed, the primary dressing stayed untouched; e) 5th day after grafts' application; f) the wound at the moment of discharge from the hospital; h) the wound 3 weeks after discharge from the hospital.

clearance of infected wounds. However none of the clinical research published to date have confirmed those results. ${ }^{17}$ Some researchers reported no change $e^{18}$ other even an increase $e^{19}[20$ in bacterial number in the course of NPWT, despite good clinical outcomes.

Due to those controversies the new concept of NPWT therapy has appeared which tries to confer more active antimicrobial properties on the wound. These include gauze containing polyhexamethylene biguanide, 21 topical irrigation with antimicrobial solution, 22 antimicrobial dressing as a wound

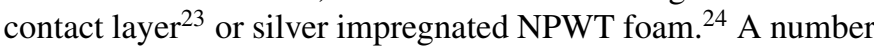
of studies have reported good clinical outcomes in the presence of these antimicrobial devices 17 22 However no studies have compared the real effect of all these methods on bacterial colonization.

In our case we used polyester tulle, impregnated with neutral triglycerides and silver ions as a wound contact layer and as a primary dressing covering skin grafts. The usefulness of silver as an antimicrobial agent has been known since antiquity and is well established in the literature. ${ }^{[25}$ It has a broad spectrum of antibacterial, antifungal and antiviral activity and it is routinely used as a topical dressing for burns and chronic wounds. Its usage has increased during the last years, perhaps because of the increased level of bacterial resistance to traditional antibiotics. ${ }^{26}$ Therefore the additional antimicrobial effect in the local environment might be crucial for elimination of bacteria in critically colonized or infected wounds. Silver resistant organisms have been reported but are extremely rare due to silver's multiple target sites. ${ }^{[27}$ The antimicrobial effect of silver is mediated by the presence of the highly reactive $\mathrm{Ag}^{+}$cation which is disruptive to many aspects of microorganism's metabolism. The mechanisms of action include: increase in production of reactive oxygen species, disruption of the mitochondrial respiratory chain, damage to the bacterial cell wall, altering DNA and RNA to prevent transcription and division. 28

Despite its advantages in treating infected wounds, silver has been demonstrated to be toxic to the cells involved in wound healing process. In study performed by Zoe et al. all silver dressings tested were found to reduce the vi- 
ability of the diabetic fibroblasts and collagen synthesis. 25 Other studies have found that silver delays the process of re-epithelialisation. 29. 30 However the clinical correlation to support this finding remains unclear. There are increasing evidence showing that silver toxicity observed in animal and in vitro models do not seem to play role in vivo 251

Silver in conjunction with NPWT could be used as commercially available foam bonded to metallic silver or typical NPWT polyurethane foam applied on a silver containing dressing which constitute the wound contact layer. Both methods are widely used because of their antimicrobial ability was confirmed in vitrc ${ }^{32}$ and on animal models. ${ }^{7}$ Unfortunately there is still dearth of data confirming their clinical effectiveness. Several authors have demonstrated good outcomes when applied to infected wounds 23.24$] 33$ or over split-thickness skin grafts $13 \sqrt[34]{34}$ however the majority of these information goes from case reports or case series which have the lowest evidence level. 17

\section{CONCLUSION}

Our experience and data from literature suggest that silver dressing in combination with NPWT may contribute to infection control and exert positive effect on wound healing and skin grafts intake. However randomize control trial should be performed to confirm that suspicion.

\section{REFERENCES}

[1] R. G. Frykberg, T. Zgonis, D. G. Armstrong, V. R. Driver, J. M. Giurini, S. R. Kravitz, A. S. Landsman, L. A. Lavery, J. C. Moore, J. M. Schuberth, D. K. Wukich, C. Andersen, and J. V. Vanore, "Diabetic foot disorders: A clinical practice guideline (2006 revision)," The Journal of Foot and Ankle Surgery, vol. 45, no. 5, pp. S1-S66, sep 2006 [Online]. Available: http://dx.doi.org/10.1016/S1067-2516(07)60001-5

[2] L. B. EBSKOV, "Diabetic amputation and long-term survival," International Journal of Rehabilitation Research, vol. 21, no. 4, pp. 403-408, 1998. [Online]. Available: http://dx.doi.org/10.1097/ 00004356-199812000-00008

[3] L. M. da Rosa and V. Radünz, "Taxa de sobrevida na mulher com câncer de mama: estudo de revisão," Texto \& Contexto Enfermagem, vol. 21, no. 4, pp. 980-989, 2012. [Online]. Available: http://dx.doi.org/10.1590/S0104-07072012000400031

[4] C. DeSantis, J. Ma, L. Bryan, and A. Jemal, "Breast cancer statistics, 2013," CA: A Cancer Journal for Clinicians, vol. 64, no. 1, pp. 52-62, oct 2013. [Online]. Available: http://dx.doi.org/10.3322/caac.21203

[5] S. Vig, C. Dowsett, L. Berg, C. Caravaggi, P. Rome, H. BirkeSorensen, A. Bruhin, M. Chariker, M. Depoorter, R. Dunn, F. Duteille, F. Ferreira, J. F. Martínez, G. Grudzien, D. Hudson, S. Ichioka, R. Ingemansson, S. Jeffery, E. Krug, C. Lee, M. Malmsjo, N. Runkel, R. Martin, and J. Smith, "Evidence-based recommendations for the use of negative pressure wound therapy in chronic wounds: Steps towards an international consensus," Journal of Tissue Viability, vol. 20, pp. S1-S18, dec 2011. [Online]. Available: http://dx.doi.org/10.1016/j.jtv.2011.07.002

[6] D. G. Armstrong and L. A. Lavery, "Negative pressure wound therapy after partial diabetic foot amputation: a multicentre, randomised controlled trial," The Lancet, vol. 366, no. 9498, pp. 1704-1710, nov 2005. [Online]. Available: http://dx.doi.org/10.1016/S0140-6736(05) 67695-7

[7] D. J. Stinner, S. M. Waterman, B. D. Masini, and J. C. Wenke, "Silver dressings augment the ability of negative pressure wound therapy to reduce bacteria in a contaminated open fracture model,' The Journal of Trauma: Injury, Infection, and Critical Care, vol. 71, no. supplement, pp. S147-S150, 2011. [Online]. Available: http://dx.doi.org/10.1097/TA.0b013e318221944a

[8] L. Krokowicz, M. Borejsza-Wysocki, J. Mackiewicz, A. Iqbal, and M. Drews, "10 years of negative pressure wound therapy," Negative Pressure Wound Therapy, no. 1, pp. 27-32, 2014.
[9] D. Walczak, R. Jaguścik, J. Porzeżyńska, W. Fałek, M. Czerwińska K. Ptasińska, L. Kozaczek, B. Krajewska, and P. Trzeciak, "Negative pressure wound therapy in the treatment of a large chronic venous leg ulceration - as a perfect method for quick wound bed preparation and support for skin grafts healing," Negative Pressure Wound Therapy, no. 3, pp. $81-5,2014$.

[10] M. Malmsjö, R. Ingemansson, R. Martin, and E. Huddleston, "Negativepressure wound therapy using gauze or open-cell polyurethane foam: Similar early effects on pressure transduction and tissue contraction in an experimental porcine wound model," Wound Repair and Regeneration, vol. 17, no. 2, pp. 200-205, mar 2009. [Online]. Available: http://dx.doi.org/10.1111/j.1524-475X.2009.00461.x

[11] N. Kairinos, A. M. Voogd, P. H. Botha, T. Kotze, D. Kahn, D. A. Hudson, and M. Solomons, "Negative-pressure wound therapy II: Negative-pressure wound therapy and increased perfusion. just an illusion?" Plastic and Reconstructive Surgery, vol. 123, no. 2, pp. 601-612, 2009. [Online]. Available: http://dx.doi.org/10.1097/PRS. 0b013e318196b97b

[12] A. K. Greene, M. Puder, R. Roy, D. Arsenault, S. Kwei, M. A. Moses, and D. P. Orgill, "Microdeformational wound therapy," Annals of Plastic Surgery, vol. 56, no. 4, pp. 418-422, 2006. [Online]. Available: http://dx.doi.org/10.1097/01.sap.0000202831.43294.02

[13] D. Walczak, R. Jaguścik, J. Porzeżyńska, K. Ptasińska, L. Kozaczek, B. Krajewska, and P. Trzeciak, "Large venous ulcers treated with negative pressure wound therapy - case report," Negative Pressure Wound Therapy, no. 3, pp. 100-103, 2014.

[14] A. Novak, W. S. Khan, and J. Palmer, "The evidence-based principles of negative pressure wound therapy in trauma \& orthopedics," The Open Orthopaedics Journal, vol. 8, no. 1, pp. 168-177, jun 2014 [Online]. Available: http://dx.doi.org/10.2174/1874325001408010168

[15] M. J. Morykwas, L. C. Argenta, E. I. Shelton-Brown, and W. McGuirt, "Vacuum-assisted closure: A new method for wound control and treatment," Annals of Plastic Surgery, vol. 38, no. 6, pp. 553-562, jun 1997. [Online]. Available: http://dx.doi.org/10.1097/ 00000637-199706000-00001

[16] R. Edwards and K. G. Harding, "Bacteria and wound healing," Current Opinion in Infectious Diseases, vol. 17, no. 2, pp. 91-96, 2004. [Online]. Available: http://dx.doi.org/10.1097/00001432-200404000-00004

[17] H. Birke-Sorensen, M. Malmsjo, P. Rome, D. Hudson, E. Krug, L. Berg, A. Bruhin, C. Caravaggi, M. Chariker, M. Depoorter, C. Dowsett, R. Dunn, F. Duteille, F. Ferreira, J. F. Martínez, G. Grudzien, S. Ichioka, R. Ingemansson, S. Jeffery, C. Lee, S. Vig, N. Runkel, R. Martin, and J. Smith, "Evidence-based recommendations for negative pressure wound therapy: Treatment variables (pressure levels, wound filler and contact layer) - steps towards an international consensus," Journal of Plastic, Reconstructive \& Aesthetic Surgery, vol. 64, pp. S1-S16, sep 2011. [Online]. Available: http://dx.doi.org/10.1016/j.bjps.2011.06.001

[18] C. M. Mouës, M. C. Vos, G.-J. C. V. D. Bemd, T. Stijnen, and S. E. Hovius, "Bacterial load in relation to vacuum-assisted closure wound therapy: A prospective randomized trial," Wound Repair and Regeneration, vol. 12, no. 1, pp. 11-17, jan 2004. [Online]. Available: http://dx.doi.org/10.1111/j.1067-1927.2004.12105.x

[19] M. Khashram, P. Huggan, R. Ikram, S. Chambers, J. Roake, and D. Lewis, "Effect of TNP on the microbiology of venous leg ulcers: a pilot study," J Wound Care, vol. 18, no. 4, pp. 164-167, apr 2009 [Online]. Available: http://dx.doi.org/10.12968/jowc.2009.18.4.41608

[20] T. Weed, C. Ratliff, and D. B. Drake, "Quantifying bacterial bioburden during negative pressure wound therapy," Annals of Plastic Surgery, vol. 52, no. 3, pp. 276-279, 2004. [Online]. Available: http://dx.doi.org/10.1097/01.sap.0000111861.75927.4d

[21] S. W. Mueller and L. E. Krebsbach, "Impact of an antimicrobialimpregnated gauze dressing on surgical site infections including methicillin-resistant staphylococcus aureus infections," American Journal of Infection Control, vol. 36, no. 9, pp. 651-655, nov 2008. [Online]. Available: http://dx.doi.org/10.1016/j.ajic.2007.12.005

[22] P. J. Kim, C. E. Attinger, J. S. Steinberg, K. K. Evans, B. Lehner, C. Willy, L. Lavery, T. Wolvos, D. Orgill, W. Ennis, J. Lantis, A. Gabriel, and G. Schultz, "Negative pressure wound therapy with instillation," Plastic and Reconstructive Surgery, p. 1, 2013. [Online]. Available: http://dx.doi.org/10.1097/PRS.0b013e3182a80586

[23] A. J. Richards, S. M. Hagelstein, G. K. Patel, N. M. Ivins, H. M. Sweetland, and K. G. Harding, "Early use of negative pressure therapy in combination with silver dressings in a difficult breast abscess," International Wound Journal, vol. 8, no. 6, pp. 608-611, aug 2011. [Online]. Available: http://dx.doi.org/10.1111/j.1742-481X.2011.00838. 
[24] R. Gerry, S. Kwei, L. Bayer, and K. H. Breuing, "Silver-impregnated vacuum-assisted closure in the treatment of recalcitrant venous stasis ulcers," Annals of Plastic Surgery, vol. 59, no. 1, pp. 58-62, 2007. [Online]. Available: http://dx.doi.org/10.1097/01.sap.0000263420. 70303.cc

[25] S.-B. Zou, W.-Y. Yoon, S.-K. Han, S.-H. Jeong, Z.-J. Cui, and W.-K. Kim, "Cytotoxicity of silver dressings on diabetic fibroblasts," International Wound Journal, vol. 10, no. 3, pp. 306-312, apr 2012. [Online]. Available: http://dx.doi.org/10.1111/j.1742-481X.2012.00977. $\mathrm{X}$

[26] A. Gabriel, J. Shores, B. Bernstein, J. de Leon, R. Kamepalli, T. Wolvos, M. M. Baharestani, and S. Gupta, "A clinical review of infected wound treatment with vacuum assisted closure $\mathbb{R}$ (v.a.c. ( ) ) therapy: Experience and case series," International Wound Journal, vol. 6, pp. 1-25, oct 2009. [Online]. Available: http://dx.doi.org/10.1111/j.1742-481X.2009.00628.x

[27] H. J. Siegel, D. F. Herrera, and J. Gay, "Silver negative pressure dressing with vacuum-assisted closure of massive pelvic and extremity wounds," Clinical Orthopaedics and Related Research $\AA$, vol. 472, no. 3, pp. 830-835, jun 2013. [Online]. Available: http://dx.doi.org/10. 1007/s11999-013-3123-3

[28] D. J. Leaper, "Silver dressings: their role in wound management," International Wound Journal, vol. 3, no. 4, pp. 282-294, dec 2006. [Online]. Available: http://dx.doi.org/10.1111/j.1742-481X.2006.00265. $\mathrm{X}$

[29] C. G. Bellinger and H. Conway, "Effects of silver nitrate and sulfamylon on epithelial regeneration," Plastic and Reconstructive Surgery, vol. 45, no. 6, pp. 582-585, 1970. [Online]. Available: http://dx.doi.org/10.1097/00006534-197006000-00009

[30] A. J. Singer and A. B. Dagum, "Current management of acute cutaneous wounds," New England Journal of Medicine, vol. 359 no. 10, pp. 1037-1046, sep 2008. [Online]. Available: http: //dx.doi.org/10.1056/NEJMra0707253

[31] K. Cutting, R. White, and M. Edmonds, "The safety and efficacy of dressings with silver ? addressing clinical concerns," International Wound Journal, vol. 4, no. 2, pp. 177-184, jun 2007. [Online] Available: http://dx.doi.org/10.1111/j.1742-481X.2007.00338.x

[32] S. Sachsenmaier, A. Peschel, I. Ipach, and T. Kluba, "Antibacterial

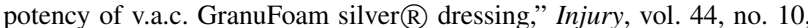
pp. 1363-1367, oct 2013. [Online]. Available: http://dx.doi.org/10.1016/ j.injury.2013.07.014

[33] L. Negosanti, A. Aceti, T. Bianchi, L. Corvaglia, F. Negosanti, R. Sgarzani, P. G. Morselli, R. Cipriani, M. Negosanti, A. Patrizi, and et al., "Adapting a vacuum assisted closure dressing to challenging wounds: negative pressure treatment for perineal necrotizing fasciitis with rectal prolapse in a newborn affected by acute myeloid leukaemia," European Journal of Dermatology, vol. 20, no. 4, p. 501-503, Jul 2010. [Online]. Available: http://doi.org/10.1684/ejd.2010.0964

[34] A. Gabriel, C. Heinrich, J. T. Shores, W. K. Baqai, F. R. Rogers, and S. Gupta, "Reducing bacterial bioburden in infected wounds with vacuum assisted closure and a new silver dressing-a pilot study," WOUNDS-A COMPENDIUM OF CLINICAL RESEARCH AND PRACTICE, vol. 18, no. 9, pp. 245-255, 2006. 